\title{
COLONIALISM AND UNDERDEVELOPMENT: CRITICAL REMARKS ON THE THEORY OF DEPENDENCY
}

\author{
by
}

\author{
RUDOLF VON ALBERTINI
}

\begin{abstract}
As historians, living in the contemporary world, we ask and are asked about the causes of underdevelopment. And, as most of the former colonies belong today to the underdeveloped countries of the Third World, we are confronted with the question as to what importance the colonial era plays in the history of these countries. There is a consensus that the history of colonialism can only be meaningful approached in the broader spectrum of underdevelopment and the specific problems of the Third World. There is no satisfaction in retreating to the ostensibly objective approach of the historian and wanting to limit ourselves in showing how colonialism came into being, what administrative structures arose, what economic policies were followed and finally how the colonized revolted and the process of decolonization got under way. Society will simply not allow us to do so. Equally, if not more important, is the question regarding the impact of colonialism on the colonized societies and how far it may be held responsible for the existing structures of underdevelopment.

This question is relatively new; before World War II and indeed in the immediate years thereafter, it would hardly have been understood. It was considered undisputable that colonialism meant progress and development, even if some aspects of exploitation were not to be denied, or if questionable projects and sins of omission might be criticized. And even if generous development aid to the colonies - or former colonies - might be proposed. Criticism of hitherto existing colonial policies, it is true, was applied in the thirties, when investigative commissions openly exposed the catastrophic social and economic conditions of certain colonies and added emphasis to the demands for active aid programmes with the help of credit from the budgets of the metropoles. The demands were, in some ways, met after the war, but it was still considered that the colonies and the countries then becoming independant step by step were in a fairly positive process of development, one which, hastened by energetic help of the rich "developed" countries, would permit a catching up to and gradual equalization with the former metropoles. Expressions such as "underdevelopment", "development policies", "development aid" arose in the fifties, heralding discussions, above all by economists, on how to formulate proper and success-promising policies to ward the developing countries in order to overcome their underdevelopment.
\end{abstract}

\section{The Theory of Dependency}

The Theory of Dependency, as it was developed in the sixties, questioned the conventional assumptions and heralded a completely new conceptual argument. It is known to have been developed by Latin American sociologists as well as by those North Americans concerned with Latin America, and was meant to serve to explain the structural problems of Latin America: continuing and actually increasing poverty in the rural areas and slums in spite of 
modern urban centres and in some cases high growth rates; the partly failed attempts at industrialization by import substitution; continued heavy dependence on a few export products and negative terms of trade; extensive foreign investment and increasing control of the local economy, mainly by American industrial corporations, and rapidly rising internal and external debt.

The theory of dependence then comes into play. I may briefly add that, according to this theory, underdevelopment doesn't mean a simple backwardness that may be caught up upon, nor merely an intermittent stage in a general process of modernization. Underdevelopment came into being through the incorporation of pre-capitalist societies into the capitalist world economic system. They have forfeited their autonomy and have become peripheries of the capitalist metropoles; a socio-economic change has taken place, but a change forced upon them and being subordinate to the interests of the metropoles. In this process of penetration, whereby on the one hand the colonies became producers of raw materials, and on the other, customers of finished products, the autochtonous societies were so deformed that their genuine possibilities of developing were hindered and structures of dependency came into being, possibilities which are almost insurmountable today, and thereby an autonomous development was prevented. Monoculture and export orientation, neglect of the food producing sectors, growing regional, sectoral and social disparities and foreign control of the modern sectors constituted the "dependent development" and thereby underdevelopment. And, because the process is continuing, it could be frankly boiled down to Frank's famous, provocative formula, "Development of Underdevelopment".

The theory of dependency has experienced various forms. There are, among others, Marxist as well as non-Marxist variations. Furthermore, it is basic to the Norwegian sociologist Johan Galtung's Theory of Structural Imperialism, in which he emphasizes the importance of bridgeheads in the process of underdevelopment. According to Galtung, the metropoles are able to keep the outlying areas dependent on them, having a bridgehead among the power elite of these outlying areas, whose interest lies with the metropoles. In addition, he holds that the so called "spin-off effect" generated by the exchange of raw materials for manufactured articles are one-sided, and are beneficial only for the industrial countries. Previously, Gunnar Myrdal had already begun to question the free trade system, in so far as he had pointed out that - analogous to the growing regional development gradient in a country - on the international scene the levelling-out function of comparative costs does not take place and the gap between developed and underdeveloped countries grows. French economists who devote themselves to the developing countries, have, moreover, come up with the theory of "unequal exchange": the exchange of raw materials for industrial goods is unequal, not only as a result of continual poor terms of trade, but also, because raw materials and foodstuffs, as well as the finished articles of the newly established industries of the Third World, are produced on the basis of a much lower wage scale than the goods of the industrial countries. The wage gap has, moreover, become greater in recent decades and accordingly the appropriation of the economic surplus by the capitalist industrial countries has increased.

So much for the theory. It has come to dominate to a large extent any discussion about underdevelopment. This new frame of analysis has, first of all, been applied to historical research on Latin America where it has actually opened up new points of view. For Africa 
and Asial) there are only just beginnings in this respect. It is above all Samir Amin, who, in a Marxist version, has publicized the theory in his numerous writings ${ }^{2}$, even when preponderantly concerned with the recent past and the present. The colonial past is only barely traced out and this results in something like the following schematic draft: Until about 1700, the modes of production and the structures of the societies in Europe, Asia and Africa are, by and large the same. With the development of capitalism in Western Europe, however, the countries outside of Europe became a peripheral part of the world trade system; the slave trade deformed and blocked African societies, while at the same time the accumulated profits of the triangular Atlantic trade made the Industrial Revolution in England possible. (This was, it is true, propounded by Marx but has long been put aside by modern industrialization researchers; even the Marxist historian Hobsbawm does not advocate this theory any more ${ }^{3)}$. It is time, I think, that Marxist economists and African historians refrained from further use of this cliché!). In turn, European industrialization requires raw materials and markets and eventually leads to the monopoly phase of capitalism with its own brand of colonialism (another cliché obstinately upheld, although it has long been recognized that one could not exactly refer to monopoly capitalism in France and England before 1914). Onesided demands in the field of export production, prevention of industrialization, and the suppression of the inchoative local bourgeoisie create the structures of "dependent reproduction" and thereby underdevelopment, which, even after the winning of political independence, is perpetuated and reinforced in the neo-colonialism of today4). Apart from Amin, Walter Rodney should also be mentioned. His book How Europe Underdeveloped Africa (1972) has found world wide circulation.

New facts are presented in a few books based on personal research,especially concerning East and Central Africa. It is certainly not fortuitous that this region is dealt with: here the settlers expropriated large tracts of land and confined the Africans into reserves, where they were kept from planting cash crops, while the numerous steps taken by the administration merely served to ensure a sufficient labour supply for the settlers and the mining industry. Given these circumstances, it is easy to hold colonialism responsible for the present day underdevelopment. Apart from this, however, the Theory of Dependency has brought but few new aspects to the history of colonialism. Older concepts such as the "colonial situation", "dual economy", "enclave economy", "lopsided economic growth", which have been used in critical writings on colonial history at least since World War II, only go to show that one has long since become aware of the meaning of dependence and "dependent development"'5)

I, therefore, don't deny that the concept of dependence presents a challenge for historical research and enables the historian better to analyze certain aspects of colonial administration and economics than has been the case so far. When, however, the present day discussion on underdevelopment tends to present the forced incorporation into the world economic system, according to the Theory of Dependency, as the only cause of underdevelopment and to blame the difficulties of the developing countries on the phenomenon of "dependent reproduction" - a term which sounds better than the older variant "colonial exploitation"- then I, as a historian, must register considerable reservations ${ }^{6}$ ). At the very least, the Theory of Dependency threatens to veil certain important aspects. Some of my reservations which I 
would like to put out for discussion are the following:

1) The Theory of Dependency makes use of a concept of underdevelopment which does not correspond to every day language. By underdevelopment the "normal user" understands an extremely low standard of living, that is, a minimal per capita income, low productivity, a low level of technical sophistication, little or no industry, a high illiteracy rate, insufficient formal and technical education, modest medical services, and a low life expectancy. In this general sense, Nepal, Afghanistan, Yemen, Ethiopia, Niger and Chad qualify as especially underdeveloped, "more underdeveloped than India, Ceylon, Egypt, Ghana and Senegal. Incorporation into the world economic system - thereby capitalism - can hardly be held as being responsible for the underdevelopment of the countries initially mentioned. This would even be true of the Sahel countries, although the decline of Trans-Saharan trading is seen as a result of the European occupation of the West African coast, and the forced cultivation of groundnuts or cotton during and after the colonial era is viewed critically. The Theory of Dependency is then forced to differentiate between underdeveloped and undeveloped. This, however, is mostly done in footnotes and annotations ${ }^{7}$ ). Undeveloped in this sense means a traditional society which has not, or only marginally, been integrated into a monetary economic system and into world trade. Furthermore, it has hardly even been confronted with a "modernization process" and the socio-economic as well as the socio-cultural effects of dependence are not felt yet, or only locally. According to the Theory of Dependency all precolonial societies are to be considered as undeveloped, although when the argument is taken futher, we see that we are concerned with autochthonous, indeed functioning societies capable of development, which were only started on the process of "underdevelopment" by the advancing Europeans and by their integration into the world economic system. Amin writes in this vein: 'Si la Côte d'Ivoire n'est plus en effet le pays primitif qu'elle était en 1950, elle est devenue un véritable pays sous-développé $\left.{ }^{8}\right)$. Another example: the old sultanate of Oman was not underdeveloped, it was undeveloped. With oil exploitation and new harbour complexes, the modern city centres, the building of hospitals and schools, the sultanate is, however, becoming underdeveloped. This has a strange and contradictory effect. Nonetheless it is consistent, when, by underdevelopment, one does not understand poverty but monoculture and external economic dependence, sectoral inequalities and marginalisation, loss of one's choice of freedom, in short when "independent reproduction" is no longer possible. If one reduces the concept of underdevelopment down to external economic dependence - and discussions on development are inclined to do this nowadays - then the no less strange conclusion arises, that rich Switzerland is underdeveloped and Canada is the "richest underdeveloped country in the world"9).

By using a specific term in another manner than is commonly used, it is suggested that international capitalism must be made responsible for the poverty and hunger in the Third World, be it in the form of the informal imperialism of Great Britain and the USA in Latin America, or colonialism or modern day neocolonialism. In simplified terms it means: Underdevelopment is the result of colonial and imperialist exploitation. Nationalist and/or Marxist historians may favour this argument in the sense of quod erat demonstrandum; I, however, think that such interpretations and assertions distort historical facts. 
Exploitation did take place and the consequences of dependence may be grave, but underdevelopment, as currently understood, is neither a consequence of exploitation nor integration into the world capitalist economic system. The historian is not searching deep enough and merely distorts - awarely or unawarely - the history of the Third World when he analyses its problems as being, to a large extent, caused only by the consequences of dependence and capitalist penetration.

2) The Theory of Dependence maintains, or at least suggests, that the colonies and the countries of the Third World, without colonialism and their integration into the capitalist world economic system, would today be prosperous nations and would possibly have become industrialized under their own steam. Japan is used to serve as evidence of this. The case concerning Japan is certainly to be taken seriously and refutes the simplified supposition that modernization and industrialization would have only been possible in the West. Every serious analysis of the development of Japan shows, however, that we are dealing with an extraordinary case, i.e., the political, administrative as well as the socio-cultural conditions at hand were especially propitious to help Japan break out of the previous isolation during the Meiji revolution, and - as in the case of Europe - to achieve the breakthrough to a self-reliant modernization and industrialization. China did not succeed in this: not only the enforced "opening up" and semi-colonial status may be held responsible, but also the lack of political and administrative unity, the inactivity of the Manchu dynasty and the aversion of the Mandarinate to socio-economic change. Countries that remained independent, such as Afghanistan and Ethiopia, that were only insignificantly penetrated by international capitalism, have not modernized themselves. In the case of India one may discuss whether an industrialization would have been possible under its own steam. Habib, certainly still the best authority on Mughal economy, arrived at a negative conclusion ${ }^{10)}$. It is historically incorrect to presuppose that the political and administrative unity created by the British would also apply to a non-colonized India: without the British conquest there would have been protracted internal wars and/or a Marathan empire -in no way suitable conditions for modernization and industrialization. In West Africa there was, needless to say, from the time of the slave trade and reinforced by the palm-oil trade a merchant class which was repressed during the colonial era. But would the African societies really have been able to develop their productive forces, so that they would today no longer be underdeveloped - underdeveloped in the sense of the Theory of Dependency? Samir Amin and with him several African historians and publicists maintain this, if only implicitly; I seriously doubt it.

3) Nationalist and Marxist historians and economists who use the Theory of Dependency and make colonialism responsible for underdevelopment, always tend to idealize the precolonial societies. The administrative efficiency of precolonial states in Africa and Asia is over-estimated in this way and is compared with the absolutist states in Europe in the 17th and 18th centuries, in order to emphasize the possibility of a transition to bourgeois capitalism; analogous to the European situation this transition did not, however, take place as a result of the European penetration and occupation. I would rather be of the opinion, that if analogies have to be made, then the Indonesian principalities, the Mughal empire and especially the other Indian powers and also the North- and black African empires and 
domains should be compared to our Middle Ages; a rudimentary administration and a flourishing luxury goods industry (since long distance trade already existed at that time). A comparison with Europe of the 17 th and 18 th centuries distorts the state of development of Africa and Asia.

Genuinely democratic societies are postulated, which were either destroyed or almost feudalized during the colonial era. In India, for instance, since Gandhi the village communities have been somewhat idolized, which with their Panchayats (village councils) are supposed to have governed themselves democratically. It is concealed or played down that these villages communities were based on a remarkably rigid caste and class system. And it is a distortion of history to reproach the colonial powers for preserving feudal structures or even creating them. It would be truer to say that the colonizer's position was based on the power of the traditional elites whose own positions of power were (unintentionally) undermined by the European takeover of the effective rule on one hand and on the other of representative councils in which the educated élite could articulate their interest and demands. Feudal élites in non-colonial areas such as Afghanistan, Iran, Arabia, Ethiopia were able to hold on far better and longer.

Another example: In discussing the Sahel catastrophe, certain commentators have held the colonial market penetration and colonialism responsible; they are blamed for the disappearance of the rich Muslim sultanates on the Southern border of the Sahara, for the decline in importance of the Trans-Saharan trade and for the dissolving of the symbiotic relations between the nomads and the agriculturalists 11 ). This is not wrong, but it is concealed or played down that the relative wealth of the sultanates was based on extensive slave trading through the Sahara; and among the Southern farmers the memory of slave raids still lives on today. The cultivation of cash crops instead of food stuffs has been made responsible for the famines and the death of livestock, but it is likewise concealed or played down that there have been periodic famines in the Sahel region since time immemorial; that the famine of the seventies occured above all in the North - in the area occupied by the nomads and that the loss of cattle was to a large extent a result of overgrazing. The size of the herds had doubled in the fifties, because the colonial administrations began systematic innoculation of the cattle. This can, in retrospective, be criticized, but clearly does not fit into the pattern of "dependent reproduction" being forced on these societies from the outside.

4) In the narrower economic field, I hold in contrast to the Theory of Dependency the very firm belief that production for export is necessary if a process of development is to take place. The world commercial system based on free trade did in fact primarily suit British interests (and in a wider sense all industrialized countries), because it made possible the acquisition of raw materials and food stuffs and the overseas marketing of manufactured goods but it nevertheless enabled the colonies and the independent Latin America countries to develop their productive powers and their import capacity. Customs duties and taxes formed the chief sources of income in the budgets, and without this revenue there would have been no possibility of building up the infrastructures, not to mention the administration, schools and medical services; loans for railroads, roads and harbours also had interest payable and had to be paid off. In addition, one tends to overlook the fact that the economic development of the USA, 
Canada, Australia and New Zealand was based on the export boom of a few products or even a single one. Japan was only able to pay for her imports of capital investment goods thanks to her exports of raw silk. External trade causes dependence, above all, when only one or a few goods are exported. The USA and the dominions were in this respect just as dependent as the "normal" colonies. It seems to me, therefore, to be wrong to make export production exclusively responsible for current underdevelopment. Hence I would not say that biased forcing of exports, which is common practice today in many developing countries (and one also promoted by the industrial countries) is ideal, but I don't think that an alternate strategy would be feasible.

The problem of colonial economics in regard to development and underdevelopment does not lie so much in the building up or cutting down of export products, important as these may be. It also partly lies in the prices of these products and the terms of trade. Bad prices and negative terms of trade also caused many headaches in the USA and in the dominions in the 19 th and 20th centuries and actually brought about recessions. What is more important here is the question of who is getting the benefits of the net proceeds and profits; this is where colonial dependence has to bear the burden. In contrast to the USA and dominions, mining and the plantations were in the hands of foreign companies, as was the marketing of products produced by peasant farming. Corporation taxes and profits went to the metropoles in addition to a good portion of the salaries for foreign personnel. Plantations and mines remained enclaves with very few supplementary effects, because the colonial powers were not interested in them.

Certainly of great importance is the structure of the societies concerned. In the North of the USA and in the British Dominions, where independent farmers produced goods for the market, the proceeds of their sales generated broadly dispersed buying power for a large quantity and variety of production and consumer goods, thereby creating the necessary markets for local industries. The Southern states of the USA and Latin America were dominated by large estates, plantations and Haciendas, which, with poorly paid and largely dependent farm labourers, only generated a low purchasing power. The big landowners were few in number and spent their income on purchasing land and luxury imports. The Theory of Dependency historians of Latin America have usually emphasized the fact that the big land and mine owners, in a coalition of common interests with the urban bourgeoisie, placed their common interest in free trade and prevented occasional attempts at introducing national industrialization through protective tariffs. In French Indo-China, the Netherlands Indies and British-India there were also - even if regionally very different-big landowners, partly of traditional origin, partly profiteers from the colonial occupation, who, by means of exorbitant rents and other duties and taxes, sucked off the agrarian surplus. The peasants, however, within their scope, were generally engaged in traditional agriculture, producing for their own use and/or for the local market. This was also true of black Africa; plantations were the exception, and especially in West Africa, it was the African peasants who also produced the cash crops.

That these millions of farmers remained poor, and the country respectively un- or underdeveloped, may only be partly attributed to the results of colonial dependence. Far more 
important was and is their low productivity, be it per unit of area or per labourer. What the peasant from Tonkin or Java, the peasant in India or Africa was able to bring to the market, was just sufficient to pay taxes, settle debts and possibly to purchase a few consumer goods.

The interpretation given by the Theory of Dependency to the colonial era and the current underdevelopment passes over and overlooks the question of agricultural productivity or one-sidedly leads it back to colonial measures such as taxes and trading profits that were too high. Whoever leaves out of his analysis not only the quality of the soil, meteorological setbacks, land/man ratio (characterized by the predominance of the smallholders), but also the inefficiency of traditional agriculture, and only theorizes about the effects of dependence is committing either an inadmissible sin of omission, or is guilty of intellectual dishonesty. The concept of "unequal exchange" also does not help much more as important as it may seem in understanding the complex phenomenon of underdevelopment: the wages of the Indian and African peasants were and remained low, because the productivity on a small holding was very low indeed. One may reproach the colonial administrations that they concerned themselves only little with production of foodstuffs, and the modest administrative help that they gave, which only accommodated the export products. But would the colonial administrations have been able to achieve very much, even with more intensive agrarian advice? The experience of the last decades does not support it. The soil and climatic conditions, traditional attitudes to agriculture, as well as the incongruity between effort expended and yield gained, not to mention the risks the peasants had to take, form obstacles and vicious circles, about which a thing or two could be told by anyone who has practical experience in development work and aid and who does not only theorize about underdevelopment at a conference table.

5) The Theory of Dependency possesses more power of assertion in regard to the question of industrialization. Especially in regard to the peculiarity of Latin American industrialization past and present it has brought forward some important insights, ones that may not be ignored in current discussions on development. This is not so much the case in analyzing colonial economics and politics, as the dependence was obvious. It is a platitude to say that the metropoles were not interested in industrializing the colonies. It certainly was not forbidden, although this is maintained nowadays in discussions on development which do not take cognizance of history; it was simply not promoted and no protective tariffs were accorded, not to mention other such measures.

Instead of always evoking the "destruction" of the Indian textile industry at the beginning of the 19th century and retrospectively accusing the colonial powers of failing to establish heavy and capital-goods industries in their colonies, it would make more sense and be more beneficial for a general understanding of the difficulties of industrialization if historians and the theories on development concerned themselves more intensively with research about "late comers". This was previously done by Gerschenkron, Kuznets, Bairoch and others. In fact it became increasingly difficult, during the course of the 19th and 20th centuries, to catch up industrially; this is not only true of the dependent colonies, but also for the independent countries of Southern and Eastern Europe. Marx believed that if Great Britain were to build railways in India, the British would also be forced to produce the locomotives there; that is to 
say industrialize India. He was mistaken, because - as Bairoch shows - he overlooked the falling transport costs. These costs enabled material for the railways to be more cheaply and easily obtained from England than it would have been to bother about establishing a heavy industry in India ${ }^{12)}$. Bairoch expounded further that the need for technical know-how and capital everywhere was steadily expanding which meant it became increasingly difficult to establish factories and to create employment ${ }^{13}$ ).

The grave fact that modern industrialization creates but few job opportunities is in my opinion far more important in achieving an understanding of the concrete difficulties of development than long-winded theoretical expositions on dependent reproduction. It is, needless to say, somewhat unconvincing when the multinationals are simply held responsible for it. Modern industry, above all the capital goods industry, is based on numerous subsidiary industries and this has greatly impeded industrialization. The research on the developing countries which is based on the Theory of Dependency tends to oversimplify the matter. On the one hand, it requires for the underdeveloped countries adapted technology and labour intensive industry, without, however, being able to state concretely which labour intensive products can in fact be produced (perhaps simple field tools, but what about fertilizer, pumps, electrical equipment?). Moreover, on the other hand, heavy and capital goods industries are considered essential even for African countries, in order to initiate self reliant independent development. But the difficulties and in some cases the breakdown of such undertakings in recent years are not discussed14). In all this, historians could perform a more worthy service. To wit: there is a widespread lack of concrete investigation of the (mostly belated) attempts at industrialization in the colonies and in the developing countries of Asia and Africa.

6) In the Theory of Dependency, the pre-colonial socio-cultural structures and patterns of behavior, which are still present today, are generally ignored. In placing the burden of the blame for underdevelopment, or rather the enormous problems faced in overcoming obstacles hindering development, on Western colonialism and neo-colonialism, the question need not be raised as to whether these obstacles hindering development are actually not to be found in socio-cultural structures of the non-western societies. In the latest research on Latin America, a more thorough interpretation seems to have indeed come to the force, whereby the integration into the world market and thereby British-American penetration from the outside is no longer held exclusively responsible for the specific structures of underdevelopment in Latin America, but rather internal factors such as the fateful symbiosis of precapitalist and late feudal elements with the capitalist profit-striving system on the Haciendas; the weakness of the state and the lack of rational efficiency in administration, the way of living, consumer habits, and traditional standards of value, which differ fundamentally from those of the achievement orientated societies of America and Europe. Only when these aspects have been considered can one plausibly explain why, for instance, the British Dominions, which were indeed for a long time peripheries of the British metropoles, have succeeded in the transition to democratic industrialized societies and this in spite of continued dependence on the export of raw materials, and, in the case of Canada, widespread control of the key industries by American corporations. 
In the cases of Asia and Africa the socio-cultural factor is doubtless even more important. Here, Max Weber's old and big question arises as to the socio-cultural provisions of modern rationality, of the willingness to produce and to save, and of the ability to plan and organise. To what extent are these provisions really compatible with the values of those living in Islamic, Hindu, or Buddhist societies? Can the problem-riddled, yet impressive industrialization achievements of South Korea, Taiwan, Hong Kong and Singapore only be explained politically and economically (massive foreign investment, low wages, repressive policies), or must it also be taken into account that we are dealing with Chinese and Koreans whose eagerness to work, produce and achieve success is well known? Historians and economists indeed hesitate to resort to vague concepts such as national character, racial peculiarities, marks of civilization, but can these, therefore, simply be excluded?

Historians and sociologists such as Hoselitz, McClelland and Behrendt who once questioned the socio-cultural pre-conditions of economic development, modernization and industrialization, seem to me to be unjustly forgotten today or even despised. They have no place in the Theory of Dependency or in historical writings influenced by it. It also seems to me time to pay more attention to the non-economic factors, as done by Myrdal15), It is a sign of inconsistency when today we are accused of ethnocentrism when we forget to respect the particularities of Asian and African societies, when on the other hand it is presupposed that these societies, had it not been for colonialism and neo-colonialism, would have developed on similar lines to those of the West.

So much for a few critical remarks on discussions on development and, increasingly, on the Theory of Dependency and its current predominant place in the history of colonialism. I again emphasize: it is a valuable new assessment and has produced important conclusions especially in regard to Latin America. It does, however, run into danger - like all new trends above all in its simplified application - of offering a one-sided explanation for underdevelopment, which does not do justice to the complexity of the problem and all too easily serves as an alibi, if need be, in holding foreign powers - be it colonialism, capitalism, the USA or the Multinationals - responsible for one's own difficulties and problems.

Historical research would do well to use it as a valuable attempt at explanation, but also to differentiate and supplement it.

1) Werner Keller, Strukturen der Unterentwicklung. Indien 1757-1914. Eine Fallstudie über abhängige Reproduktion, Zürich 1977.

2) I mention here only Samir Amin, Impérialisme et sous-développement en Afrique, Paris 1976, and "Underdevelopment and Dependence in Black Africa. Origins and Contempory Forms", Journal of Modern African Studies, 10/4 (1972).

3) Eric J. Hobsbawm. Industrie und Empire, vol. 1. Frankfurt a. M. 1969 (Editions Suhrkamp 315), pp. $38,52$.

4) For instance E.H. Brett. Colonialism and Underdevelopment in East Africa. The Politics of Economic Change 1919-39, London 1973, Colin Leys, Underdevelopment in Kenya. The Political Economy of NeoColonialism, London 1975, R. Palmer, N. Parsons (eds.). The Roots of Rural Poverty in Central and Southern Africa, London 1977

5) A good example is H.B. Lamb. "The State and Economic Development in India", in S. Kuznets (ed.). Economic Growth: Brazil, India, Japan, Durham, N.C. 1955

6) Vide my book Europäische Kolonialherrschaft 1880-1940, Zürich 1976, an American edition of which is in preparation. 
7) See also André Gunder Frank's remark in relation to the industrialized countries: "the now developed countries were never underdeveloped, though they may have been undeveloped", in his Latin America: Underdevelopment or Revolution. Essays on the Development of Underdevelopment and the Immediate Enemy, New York 1972, p. 4.

8) Samir Amin, L'Afrique de l'ouest bloquée, Paris 1971, p. 93.

9) O. Sunkel quoted in H.J. Puhle (ed.), Lateinamerika. Historische Realität und Dependencia-Theorien, Hamburg 1977, p. 66.

10) Irfan Habib, "Potentialities of Capitalistic Development in the Economy of Mughal India", Journal of Economic History, 29/1 (1969).

11) Comité Information Sahel, Qui se nourrit de la famine en Afrique? Le dossier politique de la faim au Sahel, Paris 1974.

12) Paul Bairoch, Révolution industrielle et sous-développement, Paris 1964, p. 176s.

13) Ibid., p. 166.

14) G. Arrighi, J.S. Saul, Essays in the Political Economy of Africa, London 1973, pp. 36, 273, where they are criticizing Tanzania; Dieter Senghaas. Weltwirtschaftsordnung und Entwicklungspolitik. Plädoyer für Dissoziation, Frankfurt a.M. 1977, p. 266; Samir Amin, L'Afrique del'ouest bloqué, Paris 1971, pp. 42, 44. 52.

15) Gunnar Myrdal, The Challenge of World Poverty. A World Anti-Poverty Program in Outline, London 1970. p. 12: "If our conclusions on this point are valid - that the non-economic factors, broadly attitudes, institutions, and the productivity consequences of very low levels of living. are of such paramount importance in underdeveloped countries that they cannot be abstracted from in economic theory and in planning - the second assumption, that it is possible to take account of the non-economic factors ... must be scrutinized as of crucial importance." 